\title{
Association Between Single Nucleotide Polymorphisms in the Cannabinoid Receptor Gene (CNR1) and Impulsivity in Southwest California Indians
}

\author{
Cindy L. Ehlers,' Wendy S. Slutske, ${ }^{2}$ Penelope A. Lind, ${ }^{3}$ and K. C. Wilhelmsen ${ }^{4}$ \\ ' Departments of Molecular and Experimental Medicine, and Molecular and Integrative Neurosciences, The Scripps Research Institute, La Jolla, \\ California, United States of America \\ ${ }^{2}$ Department of Psychological Sciences, University of Missouri, Columbia, Missouri, United States of America \\ ${ }^{3}$ Genetic Epidemiology Laboratory, Queensland Institute of Medical Research, Brisbane, Queensland, Australia \\ ${ }^{4}$ Departments of Genetics and Neurology, The Carolina Center for Genome Sciences, and the \\ Bowles Center for Alcohol Studies, University of North Carolina, Chapel Hill, North Carolina, United States of America
}

\begin{abstract}
Impulsivity is a personality trait characterized by acting suddenly in an unplanned manner in order to satisfy a desire without consideration for the consequences of such behavior. There are several psychiatric disorders that include the term impulsivity as a criterion and, therefore, it has been suggested that impulsivity may be an important phenotype that may link a number of different behavioral disorders, including substance abuse. This study's aims were to determine if a significant association could be detected between the (AAT)n triplet repeat polymorphism as well as 5 single nucleotide polymorphisms (SNPs) in or near the CNR1 receptor gene and impulsivity in Southwest California 'Mission' Indians (SWC). Impulsivity was assessed using a scale derived from the Maudsley personality inventory, and blood samples were collected for DNA analyses from 251 individuals recruited from local Indian reservations. The estimated heritability $\left(\mathrm{h}^{2}\right)$ for the impulsivity phenotype was $0.20+0.12(p<.004)$. Impulsivity was significantly associated with the 6-repeat allele of the triplet repeat polymorphism (AATn/A6; $p<.0001$ ), as well as four SNPs in or near the CNR1 receptor gene: $r$ 1535255 $(p=.001), r s 2023239(p=.004)$, rs1049353 $(p<.001)$ and rs806368 $(p<.0006)$. These studies provide data to suggest that the CNR1 receptor gene may be significantly associated with impulsivity in SWC Indians.
\end{abstract}

The finding and localization of cannabinoid receptors in the brain (Bidaut-Russel et al.,1990; Herkenham et al.,1990; Howlett, 2002; Matsuda et al.,1990), the genetic and physical mapping of cannabinoid receptor genes (Hoehe et al.,1991) and characterization of the endogenous cannabinoids (for reviews see Fride, 2002; Iversen et al.,2003; Onaivi et al.,2002;
Petrocellis et al., 2004; van der Stelt \& Di Marzo, 2003) and their metabolism (Fowler et al., 2001), have opened up new areas of research by which to identify potential biologic/genetic mediators of risk for, and consequences of, substance use disorders.

There have been some promising findings in association studies of candidate genes related to endocannabinoids. A polymorphic triplet repeat marker of the human cannabinoid receptor gene (CNR1) has been identified (Dawson, 1995), and has been demonstrated to be of functional relevance (Zhang et al., 2005). In one study, the number of intravenous drugs used was found to be significantly greater for individuals carrying a genetic variant of the CNR1 gene, the $>5 />5$ genotype, than for other genotypes (Comings et al., 1997). It has also been associated with attention deficit/hyperactivity disorder in Spanish male alcoholic patients (Ponce et al., 2003). Additionally, an association between the CNR1 > 5 repeat alleles and decreased amplitude of the P300 event-related potential (ERP) component was also found (Johnson et al., 1997), further supporting the importance of intermediate phenotypes in identifying genetic risk factors for drug abuse.

Several single nucleotide polymorphisms (SNPs), in or around the CNR1 receptor gene, have also been reported to be associated with drug abuse related phenotypes. A 5' CNR1 'TAG' haplotype (rs806379rs1535255-rs2023239) was found to display significant allelic frequencies differences between substance abusers and controls in European-American,

Received 3 September, 2007; accepted 2 October, 2007.

Address for correspondence: Cindy L. Ehlers, Ph.D., The Scripps Research Institute, Molecular and Integrative Neurosciences Department, 10550 North Torrey Pines Road, SP30-1501,La Jolla, CA 92037, USA. E-mail: cindye@ scripps.edu 
African American and Japanese samples (Zhang et al., 2004). The $1359 \mathrm{~A} / \mathrm{G}$ polymorphism ( $\mathrm{rs} 1049353)$ in the coding exon of CNR1 (exon 4) has also been associated with vulnerability to alcohol withdrawal delirium (Schmidt et al., 2002). Additionally, the rs806380 SNP located in intron 2 of the CNR1 gene was significantly associated with developing one or more cannabis dependence symptoms (Hopfer et al., 2006), and the (AAT)n triplet repeat polymorphism nearby the CNR1 gene was found to be associated with cocaine addiction in an African-Caribbean population (Ballon et al., 2006). However, several studies have also failed to find association of the CNR1 receptor polymorphism and substance dependence phenotypes (Herman et al., 2006; Li et al., 2000; Preuss et al., 2003).

One reason for a lack of consensus is that the various studies used different genetic markers in their association studies. Another is that different phenotypes were used and different ethnic populations were evaluated. One phenotype that may link substance dependence and other select axis- 1 disorders is impulsivity. Impulsivity is a personality trait characterized by acting suddenly in an unplanned manner in order to satisfy a desire without consideration for the consequences of such behavior. There are several psychiatric disorders that include the term impulsivity as a criterion, such as substance use disorders, paraphilias, conduct disorder and antisocial personality disorder, attention deficit/hyperactivity disorder, borderline personality disorder, pathological gambling, pyromania and kleptomania, and so on. Therefore, it has been suggested that impulsivity may be an important phenotype that may link a number of different behavioral disorders including substance abuse (Kreek et al., 2005).

Genetic studies of complex phenotypes often have advantages when they are conducted in well-defined populations, such as Native American tribes living on reservations (Lander \& Schork, 1994). The present report is part of a larger study exploring risk factors for substance dependence among Native American Indians residing in southwest California (Ehlers et al., 1998, 1999, 2001, 2004a, 2004b, 2006; GarciaAndrade et al., 1997; Wall et al., 1997, 2003). The lifetime prevalence of substance dependence in this Indian population is high and evidence for heritability and linkage to specific chromosome locations has been demonstrated (Ehlers \& Wilhelmsen, 2005, 2006, 2007; Ehlers et al., 2004b; Wilhelmsen \& Ehlers, 2005). The purpose of the present set of analyses was to determine if a significant association could be detected between the (AAT)n triplet repeat polymorphism, as well as 5 SNPs in or near the CNR1 receptor gene and impulsivity in this population.

\section{Methods}

Participants, known collectively as Southwest California (SWC) Indians (also known as 'Mission Indians'), who were of mixed heritage but at least one- sixteenth Native American, were recruited from eight geographically contiguous reservations with a total population of about 3000 individuals. They were recruited using a combination of a venue-based method (Kalton \& Anderson 1986; Muhib et al., 2001) and a respondent-driven procedure (Heckathorn, 1997), as described previously (see Ehlers et al., 2004a, 2004c). To be included in the study, a participant had to be a SWC Indian between the age of 18 and 70 without major medical problems that would preclude mobility.

Potential participants gave written informed consent, and responded to a screening questionnaire that was used to gather information on demographics, personal medical history, ethnicity, and detailed measures of substance abuse history (Schuckit, 1985), and weight $\&$ height. Each participant also completed an interview with the Semi-Structured Assessment for the Genetics of Alcoholism (SSAGA; Bucholz et al., 1994) that was used to make diagnoses (American Psychiatric Association, 1994). Impulsivity was assessed using a scale from the Maudsley personality inventory (Eaves \& Eysenck, 1975). While impulsivity is not one of the Maudsley's primary personality dimensions, the Impulsiveness questionnaire of the Eysenck Personality Scale (Eysenck \& Eysenck, 1991) is frequently used as a measure of impulsiveness and contains items derived from both the Extraversion and Psychoticism dimensions (Dawe \& Loxton, 2004). A participant scored positively on this scale if they endorsed the following 7 items: Do you long for excitement? Are you usually carefree? Do you generally do and say things quickly without stopping to think? Would you do almost anything for a dare? Do you often do things on spur of the moment? When people shout at you, do you shout back? Do you like doing things in which you have to act quickly? They scored negatively by endorsing the following two items: Do you stop and think things over before doing anything? Are you slow and unhurried in the way you move?

Two hundred and fifty-one (251) individuals had both genotype and phenotype data for this analyses. Deoxyribonucleic acid (DNA) was isolated from whole blood using an automated DNA extraction procedure, genotyping was done as previously described (Wilhelmsen et al., 2003). The total additive genetic heritability $\left(\mathrm{h}^{2}\right)$ and its standard error were estimated for the impulsivity phenotype using SOLAR (http://www.sfbr.org/solar/). The (AAT)n triplet repeat polymorphism and five single nucleotide polymorphisms (SNPs) in or near the CNR1 receptor were genotyped. The SNPs were selected based on the information available at the time from previous CNR1 association studies: the 3 SNPs that form the 'TAG' haplotype were selected based on the association findings presented by Zhang et al. (2004), and the $1359 \mathrm{G} / \mathrm{A}$ exon 4 silent mutation (Thr453Thr) from the group of Schmidt et al. (2002). Additionally, the (AAT)n copy number was recoded (AATn/45) to 


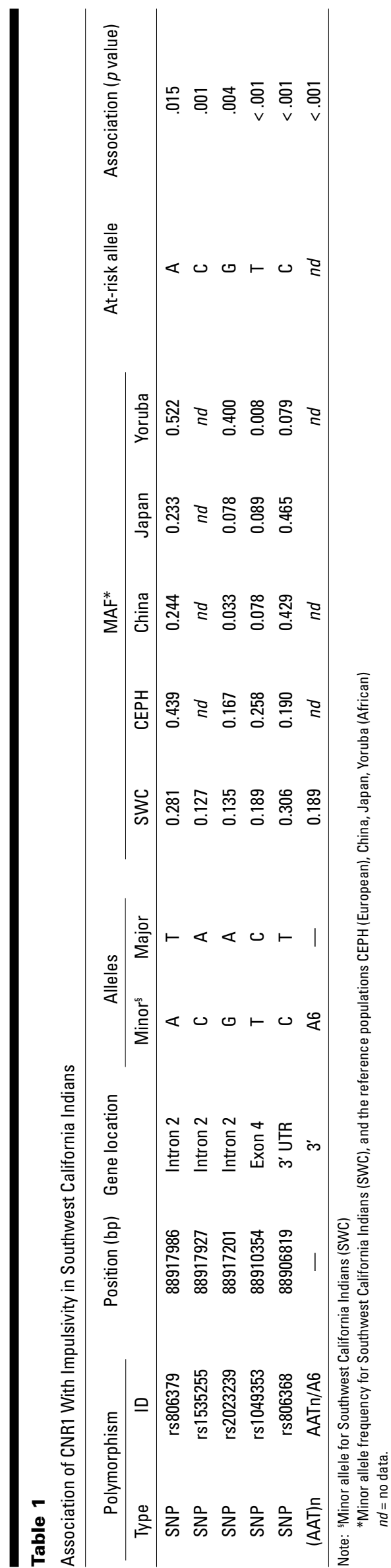

investigate the $\geq 5 / \geq 5$ repeat genotype findings of Comings et al. (1997), and to examine the affect of the 6-repeat allele *(AATn/A6). The polymorphisms typed, and their locations in relation to the CNR1 gene, are shown in Figure 1. Pair-wise marker-marker linkage disequilibrium (LD), excluding the (AAT)n triplet repeat, was assessed using the $\mathrm{r}^{2}$ statistic in Haploview 4.0 (Barrett et al., 2005), and is graphically presented in Figure 1.

All primers, probes, and reagents were purchased from ABI (Applied Biosystems, Foster City, CA). SNPs [hCV1652584 (rs806379), hCV8943758 (rs1535255), hCV11600616 (rs2023239), hCV1652590 (rs1049353) and hCV8943804 (rs806368)] were genotyped using TaqMan ${ }^{\mathrm{TM}}$ fluorescence 5' exonuclease technology, and genotypes were determined on an ABI 7900HT Fast Real-Time PCR System, using the allelic discrimination mode. The (AAT)n triplet repeat polymorphism was genotyped using the following primers: FWD 5'6FAM-GCTGCTTCTGTTAACCCTGC -3'; and REV 5'-TACATCTCCGTGTGAT GTTCC-3'. PCR fragments containing the (AAT)n polymorphism were analyzed using an ABI 3730 DNA Sequencer and the repeat size was determined with GeneMapper v3.5 software (ABI).

The total additive genetic variance (heritability, $h^{2}$ ) and its standard error were estimated for the impulsivity phenotype using SOLAR (http://www.sfbr.org/solar/). Two methods of genetic association analyses, that gave highly correlated results, were employed. In the first approach, the number of copies of the minor allele of each individual was used as a covariate in a variance component analysis, as implemented in SOLAR v2.0.4 (Almasy \& Blangero, 1998). The statistical significance of the ability of the covariate to explain phenotypic variance was determined. In the alternative strategy, a mixed model for general logistic regression, as implemented in SAS statistical software, was employed to assess the significance of genotype, taking into account the non-independence of subjects within families. The results reported are for the variance component analysis. To account for multiple comparisons significance was set at the $p<.01$ level.

\section{Results}

The demographic characteristics of the sample are virtually equivalent to the United States (US) census data for these tribes and have been presented previously (see Ehlers et al., 2004b). The mean age of the sample was $30.2( \pm 0.7)$ yrs, there were 110 males and 141 females with a mean of $11.5(0.1)$ yrs of education, $60 \%$ of the sample was over $50 \%$ Native American heritage as estimated by their federal Indian blood quantum, and $55 \%$ reported income of less than $\$ 20,000$ per annum.

The estimated heritability $\left(\mathrm{h}^{2}\right)$ for the impulsivity phenotype was $0.20 \pm 0.12(p<.004)$. Impulsivity was significantly associated with the triplet repeat 


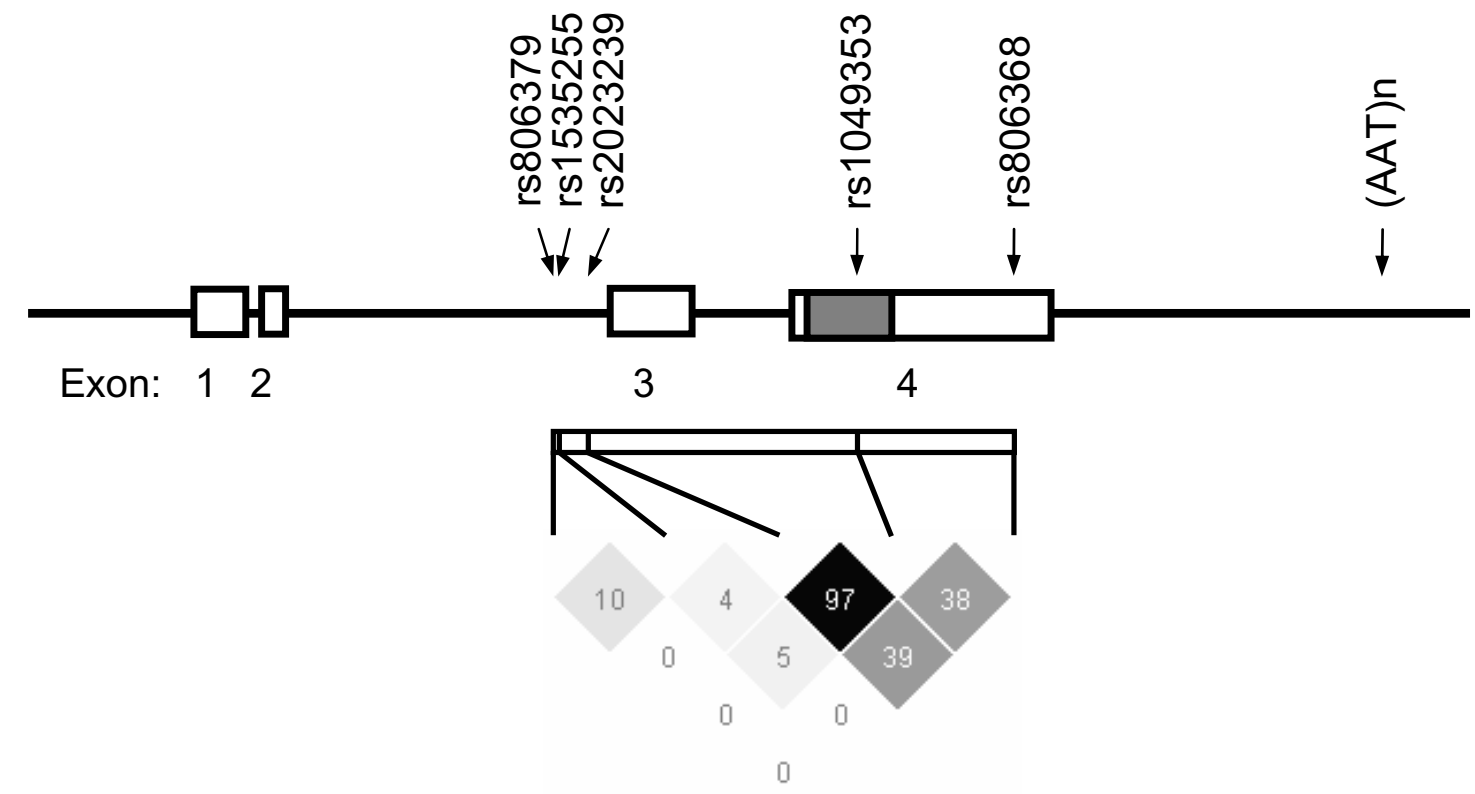

Figure 1

A schematic representation of the human $C N R 1$ gene structure and linkage disequilibrium.

The (AAT)n triplet repeat and 5 single nucleotide polymorphisms (SNPs) analyzed in this study are shown in relation to their location across the $26.1 \mathrm{~Kb} C N R 1$ gene. Exons are numbered (1 to 4) and the relative exon size is denoted by the width of the horizontal boxes. The coding region of exon 4 is indicated by the dark grey shading. Exons 1 to 3 were proposed as exons by Zhang et al. (2004). Pair-wise linkage disequilibrium (LD) between the five SNPs, as measured by the $\mathrm{r}^{2}$ statistic, is graphically presented beneath the gene structure. Regions of low to high LD are represented by light grey to black shading, respectively.

polymorphism, as well as four SNPs in or near the CNR1 receptor gene $(p<.01$; see table 1$)$. Table 1 also lists the gene location of the polymorphisms and minor allele frequencies for this SWC Indian population, as well as 4 reference populations for comparison. The 5 SNPs exhibited low to high linkage disequilibrium $\left(\mathrm{r}^{2}\right)$, comprising of one LD block spanning exons 3 and 4, as shown in Figure 1. Pairwise LD, using the $\mathrm{D}^{\prime}$ statistic also indicated a region of complete $\mathrm{LD}\left(\mathrm{D}^{\prime}=1.0\right) 5^{\prime}$ to exon 3 between rs806379 and rs1535255 (data not shown). This is consistent with LD data from the HapMap database for CEPH families of European origin in which two regions of moderate to high LD exist.

\section{$\overline{\text { Discussion }}$}

Both substance dependence and behavioral control disorders, such as conduct disorder and adult antisocial personality disorder, have been shown to have a significant genetic component to their etiology (Button et al., 2005, 2006; Cloninger et al., 1981; Grove et al., 1990; Heath et al., 1997; Kendler et al., 1992, 2003; Prescott \& Kendler, 1999; Slutske 2001). Behavioral genetics studies have the advantage in being one of the strongest methods for determining whether or not comorbidity among psychopathological conditions is due to common etiologies and/or pathologies associated with the disorders. Complex traits like substance dependence and impulsivity may be influenced by a number of genes that may be specific to the etiology of those disorders, or could overlap with other neurobehavioral disorders.

Significant evidence for a heritable component for impulsivity in this study and other substance dependence related traits, in previous studies, have been found in this SWC Indian population (Ehlers \& Wilhelmsen, 2005, 2006, 2007; Ehlers et al., 2004b, 2007; Wilhelmsen \& Ehlers, 2005). Although heritability for the impulsivity trait was only found to be modest in this population $(0.20)$ it was similar to what has been reported previously (0.36) in a primary European ancestry twin sample using a similarly derived impulsivity scale (Eaves \& Eysenck, 1975).

Impulsivity was significantly associated with the 6-repeat allele of the triplet repeat polymorphism (AATn/A6), as well as four SNPs in or near the CNR1 receptor gene in this SWC Indian population sample. The finding of an association of impulsivity with the triplet repeat polymorphism in SWC Indians is consistent with findings by others who have reported this polymorphism to be associated with: the number of IV drugs used (Comings et al., 1997), ADHD in alcoholic patients (Ponce et al., 2003), cocaine addiction in Afro-Caribbeans (Ballon et al., 2006), and decreased P300 ERP component amplitudes (Johnson et al., 1997). Additionally, the finding of significant associations with the four SNPs in or 
near the CNR1 receptor gene are consistent with the findings of Zhang et al., (2004) who found a 5, CNR1 'TAG' haplotype (rs806379-rs1535255rs2023239) to display significant allelic frequency differences between substance abusers and controls in European-American, African American, and Japanese samples.

However, several studies have also failed to find association of the CNR1 receptor polymorphism and substance dependence phenotypes (Herman et al., 2006; Li et al., 2000; Preuss et al., 2003). One reason for a lack of consensus is that the various studies used different genetic markers in their association studies. Another is that different phenotypes were used and different ethnic populations were evaluated. For instance, Pruess et al. (2003) found no association with 1359A/G (rs1049353) and alcoholism-related phenotypes, in particular, severe alcohol withdrawal, in Caucasians from southern Germany. Whereas Zhang et al. (2004) found an association with the TAG haplotype and polysubstance abuse in three populations (African American, European, Japanese).

In conclusion, these data represent the first association analysis of an impulsive behavior phenotype with the CNR1 receptor gene. The results corroborated the possible importance of the relationship between the (AAT)n triplet repeat polymorphism and substance abuse related phenotypes, as well as SNPs highlighted in prior studies of substance dependence phenotypes and also identify new SNPs of potential importance. The results of this study should, however, be interpreted in the context of several limitations. First, the findings may not generalize to other Native Americans or represent all SWC Indians. Second, comparisons of association findings to non-Indian populations may be limited by differences in a host of potential genetic and environmental variables. Finally, because this population has significant admixture, estimates of allele frequencies may produce biased results. Despite these limitations, this report represents an important step in an ongoing investigation to understand the genetic determinants associated with the development of substance use disorders in this high risk and understudied ethnic group.

\section{Acknowledgments}

This study was supported by a grant from the National Institute on Drug Abuse (NIDA)(5R01 DA019333), by a grant from the National Institute on Alcohol Abuse and Alcoholism (NIAAA) and the National Center on Minority Health and Health Disparities (NCMHD) (5R37 AA010201), the Stein Endowment fund, and by funds provided by the University of North Carolina. The authors wish to acknowledge the technical support of Heidi Feiler, Evie Phillips, Linda Corey, David Gilder, James Lee,
Samantha Segal, Michelle Dixon, Lilach Harris, Gina Stouffer, Shirley Sanchez and Philip Lau.

\section{References}

Almasy, L., \& Blangero, J. (1998). Multipoint quantitative-trait linkage analysis in general pedigrees. American Journal of Human Genetics, 62, 1198-1211.

American Psychiatric Association, Task Force on DSM-IV. (1994). Diagnostic and statistical manual of mental disorders (DSM-IV). Washington, DC: American Psychiatric Association.

Ballon, N., Leroy, S., Roy, C., Bourdel, M. C., CharlesNicolas, A., Krebs, M. O., \& Poirier, M. F. (2006). (AAT) $n$ repeat in the cannabinoid receptor gene (CNR1): Association with cocaine addiction in an African-Caribbean population. Pharmacogenomics Journal, 6, 126-130.

Barrett, J. C., Fry, B., Maller J., \& Daly, M. J. (2005). Haploview: Analysis and visualization of LD and haplotype maps. Bioinformatics, 21, 263-265.

Bidaut-Russell, M., Devane, W. A., \& Howlett, A. C. (1990). Cannabinoid receptors and modulation of cyclic AMP accumulation in the rat brain. Journal of Neurochemistry, 55, 21-26.

Bucholz, K. K., Cadoret, R., Cloninger, C. R., Dinwiddie, S. H., Hesselbrock, V. M., Nurnberger, J. I., Jr., Reich, T., Schmidt, I., \& Schuckit, M. A. (1994). A new, semi-structured psychiatric interview for use in genetic linkage studies: A report on the reliability of the SSAGA. Journal of Studies on Alcohol, 55, 149-158.

Button, T. M., Scourfield, J., Martin, N., Purcell, S., \& McGuffin, P. (2005). Family dysfunction interacts with genes in the causation of antisocial symptoms. Behavior Genetics, 35, 115-120.

Button, T. M., Hewitt, J. K., Rhee, S. H., Young, S. E., Corley, R. P., \& Stallings, M. C. (2006). Examination of the causes of covariation between conduct disorder symptoms and vulnerability to drug dependence. Twin Research and Human Genetics, 9, 38-45.

Cloninger, C. R., Bohman, M., \& Sigvardsson, S. (1981). Inheritance of alcohol abuse. Cross-fostering analysis of adopted men. Archives of General Psychiatry, 38, 861-868.

Comings, D. E., Muhleman, D., Gade, R., Johnson, P., Verde, R., Saucier, G., \& MacMurray, J. (1997). Cannabinoid receptor gene (CNR1): Association with i.v. drug use. Molecular Psychiatry, 2, 161-168.

Dawe, S., \& Loxton, N. J. (2004). The role of impulsivity in the development of substance use and eating disorders. Neuroscience and Biobehavioral Reviews, 28, 343-351.

Dawson, E. (1995). Identification of a highly polymorphic triplet repeat marker for the brain cannabinoid receptor gene: Use in linkage and association studies of schizophrenia. Schizophrenia Research, 15, 37. 
Eaves, L., \& Eysenck, H. (1975). The nature of extraversion: A genetical analysis. Journal of Personality and Social Psychology, 32, 102-112.

Ehlers, C. L., Garcia-Andrade, C., Wall, T. L., Sobel, D. F., \& Phillips, E. (1998). Determinants of P3 amplitude and response to alcohol in Native American Mission Indians. Neuropsychopharmacology, 18, 282-292.

Ehlers, C. L., Garcia-Andrade, C., Wall, T. L., Cloutier, D., \& Phillips, E. (1999). Electroencephalographic responses to alcohol challenge in Native American Mission Indians. Biological Psychiatry, 45, 776-787.

Ehlers, C. L., Wall, T. L., Garcia-Andrade, C., \& Phillips, E. (2001). Visual P3 findings in Mission Indian youth: Relationship to family history of alcohol dependence and behavioral problems. Psychiatry Research, 105, 67-78.

Ehlers, C. L., Wall, T. L., Betancourt, M., \& Gilder, D. A. (2004a). The clinical course of alcoholism in 243 Mission Indians. American Journal of Psychiatry, 161, 1204-1210.

Ehlers, C. L., Gilder, D. A., Wall, T. L., Phillips, E., Feiler, H., \& Wilhelmsen, K. C. (2004b). Genomic screen for loci associated with alcohol dependence in Mission Indians. American Journal of Human Genetics, 129B, 110-115.

Ehlers, C. L., Spence, J. P., Wall, T. L., Gilder, D. A., \& Carr, L. G. (2004c). Association of ALDH1 promoter polymorphisms with alcohol-related phenotypes in Southwest California Indians. Alcoholism: Clinical and Experimental Research, 28, 1481-1486.

Ehlers, C. L., \& Wilhelmsen, K. C. (2005). Genomic scan for alcohol craving in Mission Indians. Psychiatric Genetics, 15, 71-75.

Ehlers, C. L., Slutske, W. S., Gilder, D. A., Lau, P., \& Wilhelmsen, K. C. (2006). Age at first intoxication and alcohol use disorders in Southwest California Indians. Alcoholism: Clinical and Experimental Research, 30, 1856-1865.

Ehlers, C. L., \& Wilhelmsen, K. C. (2006). Genomic screen for loci associated with tobacco usage in Mission Indians. BMC Medical Genetics, 7, 9.

Ehlers, C. L., \& Wilhelmsen, K. C. (2007). Genomic screen for substance dependence and body mass index in Southwest California Indians. Genes, Brain and Behavior, 6, 184-191.

Ehlers, C. L., Wall, T. L., Corey, L., Lau, P., Gilder, D. A., \& Wilhelmsen, K. (2007). Heritability of illicit drug use and transition to dependence in Southwest California Indians. Psychiatric Genetics, 17, 171-176.

Eysenck, H. J. \& Eysenck, S. B. G. (1991). Manual of the Eysenck Personality Scales. London: Hodder \& Stoughton.

Fowler, C. J., Jonsson, K. O., \& Tiger, G. (2001). Fatty acid amide hydrolase: Biochemistry, pharmacology, and therapeutic possibilities for an enzyme hydrolyzing anandamide, 2-arachidonoylglycerol, palmitoylethanolamide, and oleamide. Biochemical Pharmacology, 62, 517-526.

Fride, E. (2002). Endocannabinoids in the central nervous system: An overview. Prostaglandins Leukotrienes and Essential Fatty Acids, 66, 221-233.

Garcia-Andrade, C., Wall, T. L., \& Ehlers, C. L. (1997). The firewater myth and response to alcohol in Mission Indians. American Journal of Psychiatry, 154, 983-988.

Grove, W. M., Eckert, E. D., Heston, L., Bouchard, T. J., Jr., Segal, N., \& Lykken, D. T. (1990). Heritability of substance abuse and antisocial behavior: A study of monozygotic twins reared apart. Biological Psychiatry, 27, 1293-1304.

Heath, A. C., Bucholz, K. K., Madden, P. A., Dinwiddie, S. H., Slutske, W. S., Bierut, L. J., Statham, D. J., Dunne, M. P., Whitfield, J. B., \& Martin, N. G. (1997). Genetic and environmental contributions to alcohol dependence risk in a national twin sample: Consistency of findings in women and men. Psychological Medicine, 27, 1381-1396.

Heckathorn, D. D. (1997). Respondent-driven sampling: A new approach to the study of hidden populations. Social Problems, 44, 174-199.

Herkenham, M., Lynn, A. B., Little, M. D., Johnson, M. R., Melvin, L. S., De Costa, B. R., \& Rice, K. C. (1990). Cannabinoid receptor localization in brain. Proceedings of the National Academy of Sciences of the United States of America, 87, 1932-1936.

Herman, A. I., Kranzler, H. R., Cubells, J. F., Gelernter, J., \& Covault, J. (2006). Association study of the CNR1 gene exon 3 alternative promoter region polymorphisms and substance dependence. American Journal of Medical Genetics. Part B, Neuropsychiatric genetics, 141, 499-503.

Hoehe, M. R., Caenazzo, L., Martinez, M. M., Hsieh, W. T., Modi, W. S., Gershon, E. S., \& Bonner, T. I. (1991). Genetic and physical mapping of the human cannabinoid receptor gene to chromosome 6q14-q15. New Biologist, 3, 880-885.

Hopfer, C. J., Young, S. E., Purcell, S., Crowley, T. J., Stallings, M. C., Corley, R. P., Rhee, S. H., Smolen, A., Krauter, K., Hewitt, J. K., \& Ehringer, M. A. (2006). Cannabis receptor haplotype associated with fewer cannabis dependence symptoms in adolescents. American Journal of Medical Genetics. Part B, Neuropsychiatric genetics, 141, 895-901.

Howlett, A. C. (2002). The cannabinoid receptors. Prostaglandins and Other Lipid Mediators, 68-69, 619-631.

Iversen, L. (2003). Cannabis and the brain. Brain, 126, 1252-1270.

Johnson, J. P., Muhleman, D., MacMurray, J., Gade, R., Verde, R., Ask, M., Kelley, J., \& Comings, D. E. (1997). Association between the cannabinoid receptor gene (CNR1) and the P300 event-related potential. Molecular Psychiatry, 2, 169-171. 
Kalton, G., \& Anderson, D. W. (1986). Sampling rare populations. Journal of the Royal Statistical Society, 149, 65-82.

Kendler, K. S., Heath, A. C., Neale, M. C., Kessler, R. C., \& Eaves, L. J. (1992). A population-based twin study of alcoholism in women. Journal of the American Medical Association, 268, 1877-1882.

Kendler, K. S., Prescott, C. A., Myers, J., \& Neale, M. C. (2003). The structure of genetic and environmental risk factors for common psychiatric and substance use disorders in men and women. Archives of General Psychiatry, 60, 929-937.

Kreek, M. J., Nielsen, D. A., Butelman, E. R., \& LaForge, K. S. (2005). Genetic influences on impulsivity, risk taking, stress responsivity and vulnerability to drug abuse and addiction. Nature Neuroscience, 8, 1450-1457.

Lander, E. S., \& Schork, N. J. (1994). Genetic dissection of complex traits. Science, 265, 2037-2048.

Li, T., Liu, X., Zhu, Z. H., Zhao, J., Hu, X., Ball, D. M., Sham, P. C., \& Collier, D. A. (2000). No association between $(\mathrm{AAT}) \mathrm{n}$ repeats in the cannabinoid receptor gene (CNR1) and heroin abuse in a Chinese population. Molecular Psychiatry, 5, 128-130.

Matsuda, L. A., Lolait, S. J., Brownstein, M. J., Young, A. C., \& Bonner, T. I. (1990). Structure of a cannabinoid receptor and functional expression of the cloned cDNA. Nature, 346, 561-564.

Muhib, F. B., Lin, L. S., Stueve, A., Miller, R. L., Ford, W. L., Johnson, W. D., \& Smith, P. J. (2001). A venuebased method for sampling hard-to-reach populations. Public Health Reports, 116 Suppl 1, 216-222.

Onaivi, E. S., Leonard, C. M., Ishiguro, H., Zhang, P. W., Lin, Z., Akinshola, B. E., \& Uhl, G. R. (2002). Endocannabinoids and cannabinoid receptor genetics. Progress in Neurobiology, 66, 307-344.

Petrocellis, L. D., Cascio, M. G., \& Marzo, V. D. (2004). The endocannabinoid system: A general view and latest additions. British Journal of Pharmacology, 141, 765-774.

Ponce, G., Hoenicka, J., Rubio, G., Ampuero, I., JimenezArriero, M. A., Rodriguez-Jimenez, R., Palomo, T., \& Ramos, J. A. (2003). Association between cannabinoid receptor gene (CNR1) and childhood attention deficit/hyperactivity disorder in Spanish male alcoholic patients. Molecular Psychiatry, 8, 466-467.

Prescott, C. A., \& Kendler, K. S. (1999). Genetic and environmental contributions to alcohol abuse and dependence in a population-based sample of male twins. American Journal of Psychiatry, 156, 34-40.

Preuss, U. W., Koller, G., Zill, P., Bondy, B., \& Soyka, M. (2003). Alcoholism-related phenotypes and genetic variants of the CB1 receptor. European Archives of Psychiatry and Clinical Neuroscience, 253, 275-280.

Schmidt, L. G., Samochowiec, J., Finckh, U., FiszerPiosik, E., Horodnicki, J., Wendel, B., Rommelspacher, H., \& Hoehe, M. R. (2002). Association of a CB1 cannabinoid receptor gene (CNR1) polymorphism with severe alcohol dependence. Drug and Alcohol Dependence, 65, 221-224.

Schuckit, M. A. (1985). Genetics and the risk for alcoholism. Journal of the American Medical Association, 254, 2614-2617.

Slutske, W. S. (2001). The genetics of antisocial behavior. Current Psychiatry Reports, 3, 158-162.

SOLAR (2005). Sequential Oligogenic Linkage Analysis Routines. Southwest Foundation for Biomedical Research [On-line]. Available from http://www. sfbr.org/solarl

van der Stelt, M., \& Di Marzo, V. (2003). The endocannabinoid system in the basal ganglia and in the mesolimbic reward system: Implications for neurological and psychiatric disorders. European Journal of Pharmacology, 480, 133-150.

Wall, T. L., Garcia-Andrade, C., Thomasson, H. R., Carr, L. G., \& Ehlers, C. L. (1997). Alcohol dehydrogenase polymorphisms in Native Americans: Identification of the ADH $2 * 3$ allele. Alcohol and Alcoholism, 32, 129-132.

Wall, T. L., Carr, L. G., \& Ehlers, C. L. (2003). Protective association of genetic variation in alcohol dehydrogenase with alcohol dependence in Native American Mission Indians. American Journal of Psychiatry, 160, 41-46.

Wilhelmsen, K. C., Schuckit, M, Smith, T. L., Lee, J V., Segall, S. K., Feiler, H. S., \& Kalmijn, J. (2003). The search for genes related to a low-level response to alcohol determined by alcohol challenges. Alcoholism: Clinical and Experimental Research, 27, 1041-1047.

Wilhelmsen, K. C., \& Ehlers, C. (2005). Heritability of substance dependence in a Native American population. Psychiatric Genetics, 15, 101-107.

Zhang, P. W., Ishiguro, H., Ohtsuki, T., Hess, J., Carillo, F., Walther, D., Onaivi, E. S., Arinami, T., \& Uhl, G. R. (2004). Human cannabinoid receptor 1: 5' exons, candidate regulatory regions, polymorphisms, haplotypes and association with polysubstance abuse. Molecular Psychiatry, 9, 916-931.

Zhang, Y., Wang, D., Johnson, A. D., Papp, A. C., \& Sadee, W. (2005). Allelic expression imbalance of human mu opioid receptor (OPRM1) caused by variant A118G. Journal of Biological Chemistry, 280, 32618-32624. 